\title{
Drilling Investigations on the Mechanics and Structure of Faults
}

by Kentaro Omura

Fault zone drilling provides valuable insights into understanding the dynamics, physical properties, and structure of an active fault. We drilled into the four major active faults in central and western Japan to directly access mechanics, physical properties, and fault rock distributions in and around the fault zones - the Nojima fault (which appeared by the 1995 Hyogo-ken Nanbu Earthquake, M7.2, also called the Kobe Earthquake); the Neodani fault, which appeared by the 1891 Nobi earthquake (M8.0); the Atera fault of which some parts seemed to have been dislocated by the 1586 Tensho earthquake (M7.9); and the Gofukuji Fault, which is said to have activated more than a thousand years ago. We measured in situ stress magnitude and direction in and around a fault zone by hydraulic fracturing and borehole breakout method. Additionally, integrating in situ measurements in a deep borehole and ground surface geophysical survey across a fault zone, we observed physical properties and structures of fault zones. The stress state and structure of different faults may reflect different stages in the earthquake pre-event process in the earthquake recurrence cycle.

By the in situ stress measurements, we found the differential stress magnitude decreases in the depth close to fracture zones in the Neodani fault (1300-m-deep well; Ikeda et al., 1996) and the Nojima fault (1800-m-deep well; Ikeda et al., 2001a). We also found the orientations of the maximum horizontal compressive stress were nearly perpendicular to the fault strikes of the Nojima Fault (Ikeda et al., 2001a). As for the Atera Fault, the orientation of the maximum horizontal compressive stress was the reverse of the fault moving direction (Ikeda et al., 2001b). These results support the idea that the differential stress is small at narrow zone adjoining fracture zones and the fault is quite "weak" after the earthquake. Additionally, outside the narrow zone the frictional strength of rock is still high. The level of shear stress adjacent to the fault seems to be controlled principally by the frictional strength of rock in and around the fault.

As for the Nojima fault, the pre-shock stress field adjacent to (about $300 \mathrm{~m}$ distance from) the fault was estimated by adding the stress change due to the co-seismic slip from the post-shock stress field measured by the hydraulic fracturing method (Yamashita et al., 2004). The reconstructed stress state just before the earthquake was different from that just after the earthquake and shows that the maximum horizontal principal stress direction is oblique to the fault, which is consistent with the background tectonic stress direction (East-West) before the earthquake. As for the Gofukuji fault, the orientation of the maximum horizontal principal stress adjacent to (about $300 \mathrm{~m}$ distance from) the fault was oblique to the fault trace (Omura et al., 2003a). The Headquarters for Earthquake Research Promotion, Japan determined that the Gofukuji fault has not activated for a time longer than the mean earthquake recurrence interval. The strength of the Gofukuji fault may be recovered enough to sustain shear stress on the fault, which is the same situation as estimated pre-shock stress state of the Nojima. The findings on the stress states of Nojima and Gofukuji fault suggest that the fault recovered as hard as the host rock surrounding the fault from the weak strength just after the earthquake, and that the orientation of the stress near the fault changes during the inter-seismic period of the earthquake recurrence cycle.

Downhole physical logging, and macro- and microscopic observation of recovered cores show complicated fault rock distribution in the fault fracture zones. In a schematic view, narrow strongly fractured sub-zones and broad weakly fractured sub-zones are distributed within a fracture zone. The strongly fractured sub-zones are characterized as having low electrical resistance, low density, low P-wave velocity, high porosity, and enlargement of borehole radius (Omura et al., 2003b). In particular, in the Nojima Fault cores, we observed three distinct fracture zones, each including strongly and weakly fractured sub-zones (Kobayashi et al., 2001). X-ray analyses of the Nojima fault cores show that the three fracture zones have different distribution pattern of chemical elements and alteration minerals which were produced by hydrothermal changes associated with fault activities (Matsuda et. al., 2004). The fault seems not to have slipped on a specific plane, but on more than one fault plane during earthquake cycles. The complicated fault zone structure should have formed progressively during repeating earthquake cycles.

The drilling method is of great advantage to study the mechanics and structure of fault zones because we can access the materials and internal structure of the fault zones directly. On the other hand, as the depth and the number of drillings are limited, it is important to include significant integrated studies such as geophysical prospect, geophysical observations, laboratory experiments, and numerical simulation. 


\section{References}

Ikeda, R., Iio, Y., and Omura, K., 2001a. In situ stress measurements in NIED boreholes in and around the fault zone near the 1995 Hyogoken-Nanbu earthquake, Japan. The Island Arc, 10(3/4):261-265.

Ikeda, R., Omura, K., Iio, Y., and Tsukahara, H., 1996. Scientific drilling and in situ stresses in active fault zones at Neodani, central Japan. Proc. 8th Int'l. Symp. On the Observation of the Continental Crust Through Drilling, 30-35.

Ikeda, R., Omura, K., Matsuda, T., Mizuochi, Y., Uehara, D., Chiba, A., Kikuchi, A., and Yamamoto, T., 2001b. Central Japan's Atera active fault's wide-fractured zone: An examination of the structure and in-situ crustal stress. EOS. Trans. Am. Geophys. Union, 82(47):Abstract T51A-0848.

Kobayashi, K., Arai, T., Ikeda, R., Omura, K., Sano, H., Sawaguchi, T., Tanaka, H., Tomita, T., Tomida, N., Hirano, S., Matsuda, T., and Yamazaki, A., 2001. Distribution of fault rocks in the fracture zone of the Nojima Fault at a depth of $1140 \mathrm{~m}$ : Observations from the Hirabayashi NIED core. The Island Arc, 10(3/4):411-421, doi:10.1016/j.1440-1738.2001.00339. $\mathrm{x}$.

Matsuda, T., Omura, K., Ikeda, R., Arai, T., Kobayashi, K., Shimada, K., Tanaka, H., Tomita, T., and Hirano, S., 2004. Fracturezone conditions on a recently active fault: Insights from mineralogical and geochemical analyses of the Hirabayashi NIED drill core on the Nojima fault, southwest Japan, which ruptured in the 1995 Kobe earthquake. Tectonophysics, 378:143-163, doi:10.1016/j.tecto.2003.09.005.

Omura, K., Ikeda, R., Iio, Y., Arai, T., Kobayashi, K., Shimada, K., Tanaka, T., Hirano, S., and Matsuda, T., 2003b. Logging in a fault fracture zone -A case study at Hirabayashi NIED Borehole drilled through Nojima fault. BUTSURI-TANSA, 56:401-414. (Japanese with English abstract)

Omura, K., Ikeda, R., Matsuda, T., and Mizoguchi, Y., 2003a. Active fault drilling research on stress, electrical and base rock structure - Fault zone structure of Gofukuji fault, central Japan. 2003 General Assembly of the International Union of Geodesy and Geophysics (IUGG), Poster B468.

Yamashita, F., Fukuyama, E., and Omura, K., 2004. Estimation of fault strength: Reconstruction of stress before the 1995 Kobe earthquake. Science, 306:261-263, doi:10.1126/ science.1101771.

\section{Author}

Kentaro Omura, National Research Institute for Earth Science and Disaster Prevention, Tennoudai 3-1, Tsukuba, Ibaraki, 305-0006, e-mail: omura@bosai.go.jp. 